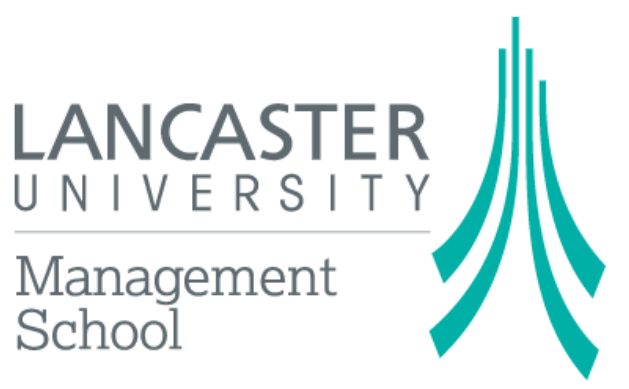

Economics Working Paper Series

2015/005

\title{
Kerala and Tamil Nadu; Differing Pathways to Development
}

\author{
Ahalya Balasubramanyam and V. N. Balasubramanyam
}

The Department of Economics

Lancaster University Management School

Lancaster LA1 4YX

UK provided that full acknowledgement is given. 


\title{
Kerala and Tamil Nadu; Differing Pathways to Development
}

\author{
Ahalya Balasubramanyam \\ V. N. Balasubramanyam \\ Department of Economics \\ Lancaster University Management School
}

February 2015

\begin{abstract}
Kerala and Tamil Nadu, neighbouring states in South India, have each in its own way attracted much attention from development economists in India and abroad. Kerala is known for its development record illustrated by the high levels of literacy of its citizens and health related development indictors. Kerala's record of development has generated debate on the primacy of growth as opposed to investments in health and education as propagators of development. Kerala is supposed to have achieved development with little growth. The other striking feature of Kerala's economy is the relatively low contribution of manufacturing to its growth and the preponderance of the services sector in both growth and employment. Tamil Nadu, in contrast to Kerala, possesses a manufacturing sector led by high tech automobiles and low tech textiles sectors amongst others. There is evidence to support the thesis that whilst Tamil Nadus's growth path over the years conforms to the Kuznets inverted $U$ curve paradigm, Kerala's growth path is far from it. This paper argues that it would be erroneous to claim that Kerala development record is based on low levels and illustrates the returns to be had from emphasising investments in health and education. That which is important for development is a flow of investible resources. Kerala in the earlier years of its development relied on public borrowing for such resources and in recent years it has had heavy inflows of remittances from its diaspora in the Gulf states. Tamil Nadu's record is largely based on growth and foreign direct investments in its manufacturing sector. This paper argues that the differing growth paths of the two states and their development record is to be traces to history and the institutions, especially the education and political institutions in place in the two states. Kerala possesses a comparative advantage in tourism and health services and should promote these sectors if it were to sustain its development record with a sustainable growth path that is not dependent on uncertain and fluctuating remittances from abroad. Tamil Nadu that has entered the services phase of the Kuznets cycle is likely to grow with services sustained manufactures.
\end{abstract}

Keywords: Growth, Development, Domar Gap, Dutch Disease 


\section{Introduction}

The economy of India is a veritable store house of controversies, conundrums, and contradictions on most development issues. Indeed, the diverse nature of the economy of India and its policies, from the pioneering import substituting industrialisation strategy to the more recent economic liberalisation strategy, provide an excellent laboratory for analysing several issues in development economics, as illustrated by the recent controversial debate, sparked by Jagdish Bhagwati's address to the lower house of the Indian Parliament (Bhagwati, 2011). Commenting on the 1991 liberalisation measures, he argued that these stage 1 reforms had provided the revenues for the stage 2 reforms that required investments in health and education to reduce poverty. It was Bhagwati's suggestion that in the absence of stage 1 reforms that generate revenues, it would be difficult to implement stage 2 reforms that led to a widespread debate on the internet and in the Indian press. Inevitably, the success of Kerala in promoting health and education and heading the league tables of human development indicators surfaced frequently in the debate. The protagonists of 'health and education first' school cited Kerala's achievements with modest growth as opposed to the relatively low record on this count by the high growth performing Punjab (Bhalla, 2011). The 'growth first' protagonists question the claim that Kerala's development record belies the growth first theory and cite the accelerated achievements of Gujarat in spreading literacy and reducing poverty preceded by growth (Panagariya, 2012). There are also comparisons of Tamil Nadu's record on development with that of Gujarat (Kalaiyarasan (2014). Tamil Nadu's record on development is shown to be superior to that of Gujarat, though the rate of growth of Tamil Nadu's income is relatively low.

Although a comparison of Tamil Nadu's record with that of Gujarat is of significance, a comparison of Tamil Nadu's growth and development record with that of its neighbour Kerala would be much more appropriate. This is so because of a number reasons including the proximate geographical location of the two states, their history, institutions, the roots of their development in trade, and the much recognised role of political leadership in framing economic policy in the two states. The issue then is 'why the differing growth and development paths of the two states?' Tamil Nadu's record more nearly approximates the Kuznets paradigm of growth than that of Kerala. This paper analyses the factors that have influenced the differing growth paths of the two states - one that appears to conform to traditional models of growth and development and the other that seems to have skipped several rungs in the traditional growth process. It suggests that the record of Kerala on development, though impressive, does not pose any conundrums as is often suggested. The record of Tamil Nadu, in fact, may be much more difficult to pin down to specific theories than that of Kerala, as it seems to be grounded in a complex set of interrelated features of the state and its citizens. 


\section{A Brief Overview of the Growth and Development Record of the Two States}

Kerala, christened God's own country by the state's tourist department, is known as much for the controversial economic and social issues it poses as it is for its scenic splendour. It was formed in 1956, with the passage of the State Reorganisation Act enabling the formation of states based on linguistic affinity, by putting together various Malayalam speaking regions of Malabar district of Madras State, Travancore Cochin and Kasaragod in South Kanara. The state is divided into 14 districts with Thiruvanthanapuram as its capital. With a land area of $38863 \mathrm{~km}^{2}$ and a population of 33.39 millions, it is ranked the twelfth largest state in the country. One of the unique features of Kerala's population is its multi religious composition, which consists of 56.2\% Hindus, 24.7\% Muslims and 19.0\% Christians. The proportion of Christians in the population of the state is said to be the largest in the country. The three groups co-exist, hailed as a "Malayalee Miracle" by Shashi Tharoor, the politician and writer. The features that stand out in the population profile of the state are the high ratio of females to males at 1084 females per 1000 males, the high density of population at 816 persons per square $\mathrm{km}$, the highest in the country, and the decline in the rate of growth of population that dates from the 1970s. The growth rate of population between 2001 and 2011, estimated at 0.49 percent per annum, is the lowest in the country.

Tamil Nadu is the eleventh largest state in India by area and the sixth most populous state in India. The Telugu, Kannada, Tulu and Malayalam parts of the state were separated from Madras state in 1956, it was renamed as Tamil Nadu in 1969. With a population of 72 millions, the state accounts for 6 percent of the country's population, the density of population at 555 is the second highest, next to Kerala amongst the four southern states. The rate of growth of population estimated at 1.56 percent between the years 2001-2011 appears to have increased marginally from 1.54 percent during the years 1991-2001. The growth rates of the domestic product for both Tamil Nadu and Kerala were not too dissimilar during the decade of the sixties. During the 1980s, the state product of Tamil Nadu increased at around 5.4\%, exceeding that of Kerala which was below $3 \%$. Since the 1990s, both states have achieved growth rates in excess of 7\%. (Table 1) Per capita income growth rates exhibit a similar trend. The share of services in NSDP of both states has increased to more than $60 \%$. Manufacturing accounts for a higher share of NSDP (20\%) in Tamil Nadu and for a low of $7 \%$ in Kerala. Services account for more than $60 \%$ of NSDP in both states.

Both the states have an impressive record on human development with Kerala outclassing all other states in the Union. Tamil Nadu ranks high on the human development index that includes income, health and education.(Appendix figure1). Their record on reduction of poverty is also impressive (Table 2 ) In sum, both states possess a record of growth and development that is superior to that of most other states including the southern states.. 
They however have followed differing growth paths that are likely to persist with implications for their further growth and development.

\section{The Classical Growth Path of Tamil Nadu}

Tamil Nadu, Gujarat and Maharashtra are the manufacturing trinity of the Indian economy. The composition of Tamil Nadu's manufacturing sector is oriented towards hi tech industries such as automobiles, machinery and equipment and basic metal industries., As Okada and Siddharthan (2008) write, "Currently, as a leading auto cluster in India, Chennai (or Tamil Nadu) accounts for 21 percent of the passenger cars, 33 percent of the commercial vehicles and 35 percent of the auto components produced in India. At present, over 100 medium and large auto companies are located in and around the Chennai cluster. In the auto component industry, Tamil Nadu has a more than 50 percent share in the production of many key parts, including engines, inlet and exhaust valves, fuel pumps, starter motors, camshafts, oil seals, wiper motors, and air brake assembly and engines". These industries have evolved over time in response to market conditions assisted by astute political and far sighted business leaders, and education establishments that provided skilled labour. The presence of sea ports in the state, especially the one in Chennai, whose development dates back to the British colonial days is also a factor in the growth of not only the automobile sector, but also the cluster of textiles and clothing firms led by the one in Tiruppur. Transportation of raw materials and food products including spices in the past from inland to the ports would have provided the incentives for the development of transport facilities such as roads and trucks. The heavy dependence of the state on monsoons has had an impact on agricultural production as seen by the low rate of growth of agricultural productivity. The green revolution though seems to have increased productivity not only in wheat and rice, but also in other crops. However, its impact on income distribution and poverty is disputed (Kurien1981, Hazell and Ramaswamy, 1999). In recent years, manufacturing industries have encroached upon agricultural land, offering attractive prices for land and the establishment of SEZs in rural areas. Whilst these developments may have enriched land owners, it may have led to the movement of the landless and jobless rural poor to the urban areas, resulting in high levels of urban poverty. This sort of a transformation of agriculture to manufacturing does not conform to the classical models of growth and structural transformation of economies of the Kuznets and Lewis type. But it may be a significant factor in the decline in the share of agriculture and the growth of manufacturing the state has witnessed. Tamil Nadu's share of manufacturing in the NSDP at around $19 \%$ in the year 2013/14 is highest among the southern states and higher than that for the country as a whole. The contribution of services has also grown over the years and stands at $60 \%$. The software industry accounts for a high proportion of services in the state. 
The change in the structure of the economy in recent years reflects the state's positive response to liberalisation and the exploitation of the comparative advantage the state possess in infrastructure and skilled labour. The structural change of the state's economy conforms to the Kuznets paradigm with a few qualifications. First, the growth of the manufacturing sector does not seem to be preceded by growth in productivity of the agriculture sector. In fact, sales of land to industrialists and SEZS, because of the attractive prices offered for land or what may be termed as distress sales appears to have promoted manufacturing (Vijayabaskar 2010).

Second, the paradigm rests on the observation that as per capita income increases, income inequality increases at first, flattens out with further growth of incomes and then begins to decline. This is the so called inverted $U$ curve. These changes in income inequalities reflect growth in incomes of the lower income groups catching up with the upper income groups. Data reported by the Planning Commission shows that income inequalities, measured by Gini coefficents of consumption, declined in rural areas and increased in urban areas (table 4). Transformation of the economy of the state appears to conform to the Kuznets paradigm. The high growth rates of the manufacturing and services sectors, that date from the year 2000, appear to have increased income inequalities in the urban areas. The decline in income inequalities in rural areas may be due to growth of non -farm employment promoted by rural industries rather than growth in the productivity of agriculture.

The pattern of growth and development of Tamil Nadu's economy also illustrates the role of institutions in promoting development, especially so in a democracy. Caste is portrayed as one of the institutions in Tamil Nadu that has promoted the growth of manufacturing industries such as textiles in Tiruppur. The cohesion between members belonging to a particular caste promotes financing and marketing according to some commentators. Vijayabaskar and Kalaiyarasan (2014), convincingly demonstrate the fallacy of this pro-caste view based on a case study of the Tiruppur textile cluster. Members of a particular caste in charge of exporting clothing and textiles had no hesitation in exploiting the members of their caste, the producers, to whom they had subcontracted the exports. This is a case where one group of well-endowed members of a particular caste exploit the less wellendowed. Caste, however, may influence political outcomes in a democracy. The votes possessed by the vast number of poor and deprived lower castes may be of significance in deciding outcomes of elections. Thus both the DMK and AIDMK parties have wooed the poor of the lower castes with various sorts of subsidies. The PDS is a case in point. The public distribution of subsidised food has had a role in reducing poverty in the state especially in the rural areas.

Farsighted political leadership and business entrepreneurship have also played a role in the growth of the Tamil Nadu economy on the classical growth path. In the past, politicians such as TT Krishnamachari and business leaders such as T V Sundaram lyengar had a role in the 
birth and growth of industries such as the automobile industry, the pride of Tamil Nadu. So too have the education institutions such as the Guindy Engineering college in providing a steady stream of technicians and engineers for the manufacturing and software sectors of the state. In sum, institutions, political leadership and inheritance from history have all contributed to the classical growth path of Tamil Nadu economy.

\section{The Growth Path of Kerala}

Kerala differs from its neighbour Tamil Nadu in more ways than one. Its growth rate increased dramatically from around the mid-eighties. Until then, the rate of growth of the Kerala economy was on par with the Hindu growth rate of the economy of the country as a whole. Indeed, available data shows that the rate of growth of Kerala's per capita income was substantially lower than that of other states for the decades of the 1970s and the 1980s. It is Kerala's well known record on development including high literacy rates for both men and women, low infant mortality, low levels of poverty and long years of life expectancy, all achieved with a low growth rate that has attracted much controversy.

High levels of development with low growth is often referred to as the Kerala model. Whilst some commentators talk of the Kerala experience, rather than the Kerala model, that may have lessons for other states, they do not address the most obvious question - where did the resources for investing in health, education and the well- being of the old and the infirm come from? It is facile to say that the programme of social development was led by the state; for the state cannot create resources out of thin air. There is no escape from the fact that the state has had access to resources from the traditional sources - growth, public borrowing and remittances from abroad; growth during the pre-independence days, extensive borrowing during the low growth decades and remittances since the decade of the eighties. Growth is but one of the sources of investible funds though a most important one. Resources can also be borrowed and solicited through aid and transfers from other regions. As is extensively analysed (George KK and Krishna Kumar KK (2003) George KK (1990), Tharamangalam(1998)) the state resorted to the ruse of utilising funds from the capital account of the state budget for expenditures on the current account. Expenditures on education, health, pensions on the current account increased cumulatively and so did the payments for servicing the borrowings on the capital account. The state also dipped into public accounts - state provident funds and treasury savings deposits until the recently The state promoted investments in treasury bonds and provident funds with a competitive interest rate paid on these deposits. This could be one way of funding the state expenditures in addition to taxation in the absence of a right to resort to deficit financing. Kerala outperforms most of the other states of the Indian union in the volume of public debt it has raised to fund its expenditures. The fiscal record of the state during the seventies and the eighties was in stark contrast to that of most other states. Whilst with devolution of 
funds from the Finance Commission, all other states in the union posted a surplus on the current accounts of the budget, Kerala experienced a deficit in six out of the 14 years from 1974-75 to 1987-88. Since the mid-eighties, Kerala's fiscal deficit as a percentage of its NSDP has exceeded that of most other states. Fiscal deficit has hovered around $4 \%$ and above for most of the years since 1985-86 to the present. Although there are signs of improvement in the fiscal health of the state in recent years, it continues to run high levels of debt. Kerala's per capita debt of Rs 19,626 in the year 2010 was much higher than that for Karnataka estimated at Rs 8901, and Rs 9692 for Tamil Nadu. Per capita fiscal deficit of Kerala in recent years stood at Rs 1638 compared with Rs 50.33 for all other states (Ministry of Finance 2013). Indeed, with rare exceptions, the current account of the budget was in deficit during most of the years, well into the recent years for which data are available (KK George and Krishna Kumar2003, Jeromi (2003) (Tapas Sen 2012)). This method of funding state expenditures adds to the interest rate burdens of the state.

Figure 1. Fiscal Deficits in Kerala's Budget

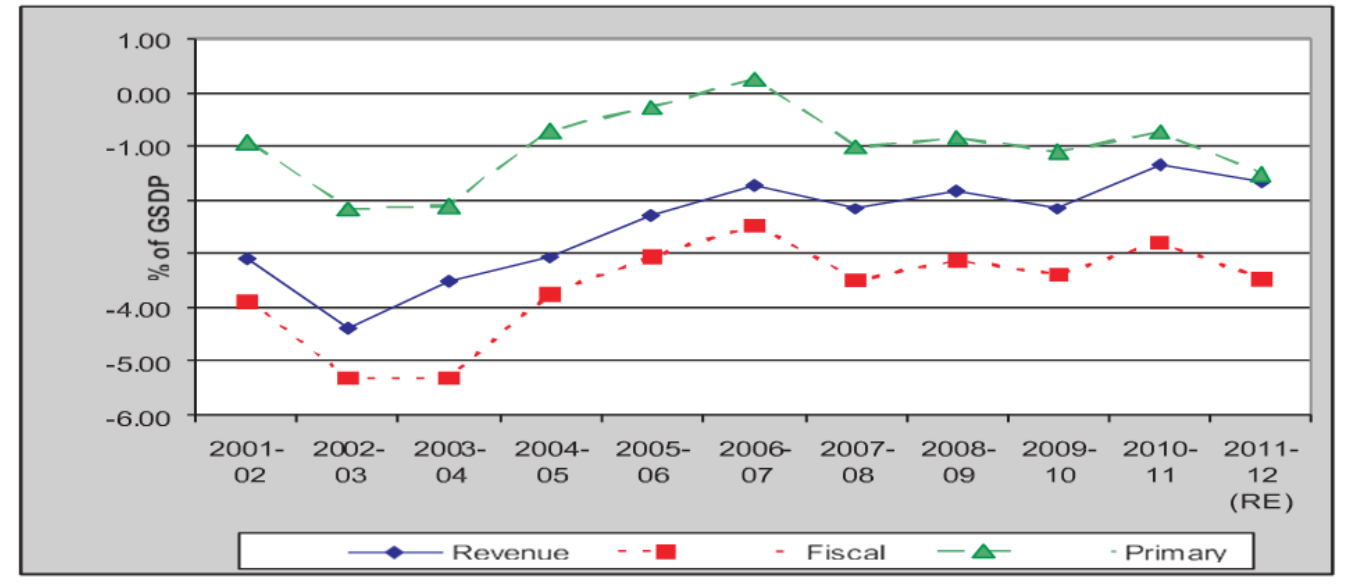

In addition to borrowing from the markets, the state has also obtained ways and means advances and overdraft facilities from the Reserve Bank of India during the latter half of the 1990s and first half of the decade of 2000 for which data are reported. The number of days for which this sort of advances was obtained exceeded 200 in the case of ways and means advances and 100 for overdrafts (Jeromi 2005).

Heavy borrowing in itself may not constitute a threat to the economic stability of the state. Borrowed funds wisely spent on growth promoting projects can yield tax revenues to service the debt including repayments. The expenditures of the state on social objectives including education, health and pensions with very little investments in growth promoting projects poses a threat to the long run economic prospects for the state. Indeed, much of the borrowed funds, about $80 \%$ of it each year according to one source, is devoted to repayment of old debts incurred to fund its expenditure on the current account of the budget. 
The high creditworthiness of the state may account for its access to a diverse range of sources of finance. The Economic and Political Weekly (Kerala in a Debt Trap, March 13, 2004) reports that Kerala enjoys a high credit rating and its bonds are mopped up quickly in credit markets. Kerala receives a fair share of its debt from external sources as well: the Dutch and Swiss governments and the Asian Development Bank (ADB) to name a few. Kerala owes its favourable credit rating in recent years to its high growth rate that exceeds the rate of interest resulting in decreasing fiscal deficits and a favourable balance between growth rate and the rate of interest known as the Domar gap (Table 5). The Domar gap shows the difference between the nominal interest rate and the growth rate in nominal terms. As long as the nominal growth rate is higher than the nominal interest rate, the state can borrow and repay the loans. Indeed, the real rate of interest may be negative if the rate of inflation in the economy exceeds the nominal rate of interest. It is likely that lenders to the state of Kerala may suffer from the so called money illusion, they may assess the strength of the economy on the basis of the high nominal growth rates ignoring the rate of inflation that reduces the real growth rate of the state product.

The other significant development that has contributed to growth and development since the mid-eighties is the growth in remittances from Kerala's diaspora in the Gulf. The number of emigrants from the state swelled from a mere 0.23 million at the beginning of the decade of the 1980 s to an estimated 2.18 million in the year 2008. So too have remittances from the emigrants in the Gulf to their dependents back home in Kerala. Available data show that remittances increased from Rs136, 250 million (\$2230 million)in the year 1998 to Rs496,950 ( $\$ 8129$ Million) in 2011. Latest estimates show that remittances had reached a staggering Rs 809.100 million ( $\$ 13,244$ million) by September 2013. Remittances that amount to $31 \%$ of the state's domestic product, 1.74 times the states domestic revenue and 5.5 times the finances received by the state from the centre have sustained the relatively high growth rate of the state.

The decline in the share of agriculture in the economy referred to earlier, the high proportion of services and the significant growth in income inequalities characterise the growth path of the economy along with the splendid record of the state on human development. None of these features can be attributed to the sort of economic transformation associated with the Kuznets paradigm. Share of agriculture has declined in the state product not so much because of growth in productivity, but because of the so called Dutch Disease or what may be much more aptly described as the Malayalee Malaise. Growth in income inequalities too is to be ascribed to remittances. The admirable human development record is a product of the unique institutions in the state.

The impact of the considerable inflows of remittances in foreign exchange into the state is cast as a variant of the Dutch Disease (Balakrishnan 2012). The Dutch Disease phenomenon was first identified in the Netherlands following the upsurge in the foreign exchange rate of 
the Guilder arising from the discovery and exports of gas. The rise in the exchange rate reduced exports of goods other than gas and increased imports that competed with domestic industries. This phenomenon has also been observed in the case of countries that have discovered oil and other exports with a high demand in international markets. In most cases, the price of non-traded goods, mostly services, increases relative to traded goods following a growth in productivity and increase in the volume of exports of specific goods such as oil. The increase in the ratio of the price of non-traded goods to that of traded goods has two principal effects. One is the resource allocation effect and the other is the spending or expenditure effect. The latter increases demand for non-traded goods including housing, education and medical services and the former shifts resources, principally labour, from the traded sectors to the non-traded sectors. In the first phase of the disease, resources move from sectors other than the booming export sector to the non-traded sector, in the latter phase they move from the booming sector too into the non-traded sectors (See Corden and Neary ,1982 Balakrishnan 2012 for detailed discussion of the phenomenon).

Kerala has been inflicted with the disease not because of the discovery of oil or gas, but because of the inflow of foreign exchange in the form of remittances. The spending effect of the inflows has been considerable. Zachariah and Irudaya Rajan (2014) have comprehensively analysed various aspects of the remittances saga of Kerala in a series of articles and books. One feature they cite that jells with the Dutch Disease model is that the recipients of the remittances spend most of their riches on education of their children, health, paying off debts and dowries and more importantly on housing. It is of significance that private health care in Kerala has grown at a much faster pace than public health care. During the years 1986-1996, there was a $40 \%$ growth in the number of private sector hospital beds from 49,000 to 67,500 , whilst the growth in public sector beds was a mere $5 \%$ from 36,000 to 38,000 . In recent years, housing and health continue to be significant items of expenditure of the recipients of remittances. Household durable goods also account for a significant proportion of their expenditure. Per capita consumer expenditures in both rural and urban areas in the state have been consistently higher than that for the other three southern states and India as a whole since the year 1983. This growth in consumer expenditures, especially on non- traded services such as education, health and construction concurs with the Dutch disease oriented spending effect. In fact, services now constitute for more than $65 \%$ of the gross domestic product of the state.

The exponents of the Dutch disease hypothesis in the context of Kerala identify the existence of resource allocation effect centred on the decline of agriculture, especially the steep fall in the output of rice since the mid-seventies accompanied by rising real wage rates. The increase in wage rates that exceeded the increase in yields coupled with rising land prices fuelled by the demand for housing by the recipients of remittances are all factors in the decline of agriculture since the mid-seventies (Kannan and Pushpangadan (1988). The proponents of the Dutch disease hypothesis attribute the decline in rice production in 
particular and agriculture in general to the emigration of labour to the gulf. It is not that agricultural labourers downed tools and hopped on planes to the Gulf States, rather it is the increase in wage rates that sets off the resource allocation effect. The construction sector in the oil rich Gulf, with wage rates several time higher than that at home drew labour, mostly low skilled construction workers, to the Gulf. It is the presumption that labour in the agricultural sector moved to occupy the space vacated by the migrants in the domestic construction sector that has benefited from the spending effect.

The Dutch Disease phenomenon provides the explanation for the significant change in the composition of the state product. It also is responsible for the growth in income inequalities with the Gini coefficient reaching 0.40 in recent years. In sum, investment in education and health funded by borrowing in the earlier years and remittances since the late eighties accounts for the phenomenon of development with low growth in the state. The so called Dutch Disease, a consequence of inflow of remittances from the Gulf, accounts for the structural transformation of the economy.

Whilst these developments account for the sort of growth path that resembles the Kuznets paradigm, but has none of its preconditions, significant institutional features that have shaped the economy cannot be ignored. Growth without development is a much observed phenomenon in many countries. Kerala could have squandered the resources it borrowed and the remittances it received, the remittances could have greased the palms of the politicians and administrators and growth could have come to dead end. None of this has ensued. The significant reason for the record of Kerala on human development is the presence of institutions of the sort that promote development. First is the contribution of the Christian Church to the spread of literacy in the state. As One of the clergy, whilst discussing the contribution of the Church to Kerala's development, remarked "we sow they reap", meaning that the investments in education by the missionaries had benefited the Hindus and the Muslims alike (author's interviews).

Second, The Muslim population of the state is the main though not the only source of emigrants to the Gulf and the remittances the emigrants provide. The high proportion of Muslims in the state is a consequence of the involvement of Arabs in the spice trade that stretches back into history. It is mostly the Muslims that account for the large proportion of emigrants to the Gulf States whose remittances sent back home has had a significant impact on the economy of Kerala. The cosmopolitan structure of the population of Kerala is to be attributed not so much to the imposition of their creed by the conquerors from abroad on the local population, but to an assimilation and acceptance of the foreign creed bestowed on them by the merchants of trade with all the fruits of trade. Another factor in the three pronged religious mix of the population of the state is intermarriages between the traders and immigrants and the indigenous population. It is thus that coexistence rather than conflict is a feature of the multi-religious population of Kerala. 
Third, the state has a reputation for excellence in health services and health education including traditional medicine. This too is in part a contribution of the Christian Church. Nurses and midwives account for a significant proportion of the emigrants to the Gulf.

Finally, of equal significance as the religious mix in the development record of the state is the presence of political institutions devoted to the promotion of equality. Kerala is known for its left leaning political parties. Politics in Kerala is dominated by two coalition fronts: the Communist Party of India(Marxist)-led Left Democratic Front (LDF) and the Indian National Congress-led United Democratic Front (UDF) since late 1970s. These two coalitions have been alternatively voted to power since 1982. The major political parties in Kerala, except for the Bharatiya Janata Party (BJP), belong to one or the other of these two alliances and have, in the past, shifted allegiances a number of times. Most of the parties, including the Congress party, are ideologically left wing or socialist-oriented, a feature that is unique to Kerala in the Indian union. The ideological orientation of the parties, strong labour unions in the state and the presence of numerous citizens groups are all a product of the campaigns led by savants such as Shree Narayana Guru against the caste system and the domination of the economy by the upper castes. The ideological left wing orientation of the political parties is largely responsible for the birth and growth of public institutions including the panchayath raj and other decentralised institutions in Kerala. These institutions are of the sort that Acemoglu and Robinson (2002) refer to as inclusive institutions that are both sufficiently centralised and pluralistic. In this context, the observation of a commentator on the role of institutions in the effectiveness of the public food distribution system (PDS) in Kerala is worth noting;

"In Kerala, a long history of grass-roots activism and political mobilization from below has meant that leakage is low (state accountability and popular mobilization are mutually reinforcing) and distribution reaches the proper constituencies with little loss. In Bihar conversely, leakage is exceptionally high, beneficiaries small, and food security is accordingly low. Mooij's argument turns on how populist politics in the state is of a different sort in which (1) politicians do not require food to increase their popularity, (2) politicians cannot make PDS function in such a way as to make political capital out of it, (3) the diversion of PDS to the black market is a greater source of profit than targeting food insecure constituencies, and (4) some of the households are too poor for PDS. In both cases, the actual forms of democracy - one a redistributive politics associated with Marxist parties, and the other a decrepit and corrupt sort of authoritarian populism - have to be grasped in all of their local complexity to identify the ways in which food enters, so to speak, the social contract" ( Watts,2000).

It is the presence of institutions devoted to the promotion of equity that have earned it first place on the league tables of corruption as the least corrupt state in the country. The low level of poverty in the state is largely due to the PDS managed efficiently with low levels of corruption. As one commentator notes" "This resilience..., is the outcome of the unique strategy of development followed by the state, fostering human development first and 
allowing economic growth to trail - distinguishing itself from other small open economies whose growth fortunes are solely dependent on the vagaries of developments elsewhere(Suresh Babu, 2005).

There is truth in this statement, but it needs to be qualified. Economic growth has not trailed, especially since the mid-eighties. The strategy of development followed by the state in the earlier years as discussed above did generate resources not by growth, but by borrowing. There are also other features of the economy of Kerala that sets it on a path far from the Kuznetsian one and is disquieting. This has to do with the high levels of unemployment in the state. In 2011, 1.05 million of Kerala's population was unemployed, i.e., 465,000 males and 580,000 females. The unemployment rate (as percent of labour force) was $10.5 \%$ in 2011, 6.4 among males and $22.3 \%$ among females. According to the current daily status approach, Kerala's unemployment rate for those aged between 15-59 years was $16.5 \%$ against the national average of $5.8 \%$. Unemployment rate in Kerala for persons of age 15-59 years in 2011-12 as per Usual Principal \& Subsidiary Status (UPSS) approach was $7.4 \%$ behind two small states viz; Nagaland (18.7\%) and Tripura (13.6\%), as against the national average of $2.3 \%$. This indicates that the rate of unemployment in Kerala was almost three times the all India rate.

The high rate of unemployment in the state sits uncomfortably with the high rates of literacy and education of the population in the state. There may be several explanations for the growth without jobs phenomenon. First, there may be a mismatch between the sort of skills the job seekers possess and the jobs on offer. Job seekers who are educated with secondary school leaving certificates account for a high proportion of the unemployed. Whilst they may not be suitable for or opt for manual labour in construction, they may be underqualified for jobs in the skill intensive occupations such as banking and finance. Second, most educated job seekers, especially those with degrees in the social sciences in Kerala, prefer jobs in the services sector. In the year 1989 in response to an advertisement by the Kerala Public Service Commission inviting applications for a few jobs as bus conductors, the Commission received 268000 applications, 20\% of these were post graduates. The required qualification for the job was only a high school diploma (Tharamangalam, 1999). Third, Kerala produces very few engineers and doctors per one thousand population compared with the other three southern states. All of this has resulted in high levels of educated unemployed. Yet another anomaly is the significant number of immigrant labourers into Kerala, in the face of high levels of local unemployment, from other states in India especially West Bengal, Assam and Bihar. Latest estimates put the number of immigrants at 2.5 million with an annual inflow of 0.23 million (Narayana and Venkiteshwaran, 2013). Sixty percent of the immigrants work in construction and the others are spread across the services sector including hotels, restaurants and trade. The presence of immigrant labour amidst a large pool of unemployed domestic labour is explained by two factors. Immigrants work for longer hours and enjoy none of the social security benefits. 
Equally significant is the preference of well-paid local labourers for leisure as opposed to work. In the economists jargon, the supply curve of local labour is backward bending. At relatively low wages, they substitute work for leisure, but as their wage rates move up or they receive remittance from abroad, they substitute leisure for work. Statistical evidence on the backward bending supply curve, though scanty, shows that this sort of a backward bending supply curve may be a feature of unskilled labourers in the state. It is also the case that the number of unskilled labourers not in the labour force was higher in households receiving remittances than households without remittances (Sindhu Jasleen2007). There is a twist to the backward bending supply curve of labour that may be termed as disguised unemployment that exists in the construction industry in some regions of the state. These are the so called "watch coolies" who are on the work site supposedly supervising the hard working immigrant labourers, but doing nothing other than watching the workers They do get paid the wage rate prescribed by the unions arguably much higher than their marginal product.

\section{Conclusions}

The two southern states, each with a hoary history, present contrasting pictures of development. Neither of them has trodden the path of development based on an initial growth in productivity of agriculture. But the share of agriculture in the income of both states has declined. In the case of Tamil Nadu, industry has encroached on agriculture in more ways than one and the sector's dependence on monsoon rains has not helped. Kerala's plantation agriculture has suffered both because of the liberalisation of imports of plantation products and the Dutch Disease generated by remittances. Services account for a high proportion of income in both states, but in the case of Tamil Nadu, it is a progression on the path recognised by Kuznets. In the case of Kerala, it is promoted by remittances, not a reliable permanent stream of income. In both states, institutional factors have played a role in the growth paths they have adopted. In Kerala, the institutions are shaped mostly by history with the promotion of equity as the objective. In Tamil Nadu, they are shaped by the resource endowments and political forces keen on growth. Whilst Tamil Nadu is likely to continue to tread the Kuznets path, Kerala's prospects for maintaining its high level of growth and development is heavily dependent on an uncertain source of incomeremittances. The state has to invest its present largesse in areas in which it has a comparative advantage - services centred on health services and tourism including health oriented tourism. It would also be worthwhile for the state to rejuvenate its plantation sector and exports of plantation products. 


\section{References}

Acemoglu Daron and Robinson James (2002), Why Nations Fail; The Origins of Power, Prosperity and Poverty, Barnes and Noble, New York

Balakrishnan P (2002)" Why Did a Slump Follow Land Reforms in Kerala?" South Asia Economic Journal 3: 51.

Bhagwati (2011) Indian Reforms: Yesterday and Today in Mehta P and Chatterjee B (ed) Growth and Poverty,; The Great Debate CUTS International, Jaipur.

Bhalla (2011) Comment in Indian Reforms: Yesterday and Today in Mehta P and Chatterjee B (ed) Growth and Poverty,; The Great Debate CUTS International, Jaipur

Corden W M and Neary JP (1982)" Booming Sector and deindustrialisation in a small open economy," Economic Journal, volume 92 December

George KK and Krishna Kumar KK (2003) Fiscal Management in Kerala ; Constraints and policy options, working paper number 9, , Centre for Socio-economic \& Environmental Studies(CSES). Kochi

George KK (2011)"Kerala Economy: Growth,Structure and Weakness," Working Paper number 25 Centre for Socio-economic \& Environmental Studies(CSES). Kochi

Hazell and Ramaswamy,(1999) The Green Revolution Reconsidered: The Impact of High Yielding Rice Varieties in South India

Jeromi, (2005) Economic reforms In Kerala, Economic and Political Weekly July 23

Kalaiyarasan A (2014,) A Comparison of Development Outcomes in Gujarat and Tamil Nadu Economic and Political Weekly VolXL1X April 12

Kannan and Pushpangadan (1988) Agricultural stagnation and economic growth in Kerala: an exploratory analysis, Centre for Development Studies, Trivandrum

Kurien T. C (1981) Dynamics of Rural Transformation: A Study of Tamil Nadu, Orient Longman, Madras

Narayana and Venkiteshwaran, (2013) "Domestic Migrant Labour in Kerala", Gulati Institute of Finance and Taxation,

Okada A and Siddharthan N S (2008) Industrial Clusters in India: Evidence from Automobile Clusters in Chennai and the National Capital Region Chapter 5 in Akifumi Kuchiki and Masatsugu Tsuji (eds.) The Flowchart Approach to Industrial Cluster Policy, London: Palgrave-Macmillan, (2008), pp. 109-144)

Panagariya A (2012) Cracking the Kerala Myth Times of India, 2 January

Sen Tapas (2012) Recent Developments in Kerala Finances, Working Paper 449, Centre for Development Studies, Trivandrum

Sindhu Jasleen (2007) Impact of Economic Liberalisation on Regional Disparities in India, Doctoral Dissertation, Department of Economics, Lancaster University, Lancaster

Suresh Babu, (2005) Kerala's Growth Trajectory, Economic and Political Weekly July 23

Tharamangalam Joseph.(2006) “ Understanding Kerala' Paradoxes; The Problematic of the Kerala Model of Development" In Tharamngalam Joseph (ed) Kerala the paradoxes of public action and Development, Orient Longman Private Limited, New Delhi

Vijayabaskar (2010): "Saving Agricultural Labourfrom Agriculture: SEZs and Politics of Silence in Tamil Nadu", Economic \& Political Weekly, Vol 45, No 6, pp 36-43)

Vijayabaskar and Kalaiyarasan (2014) Caste as Social Capital; The Tiruppur Story, Economic and Political Weekly, March 8, Volums XLIX Number 16 
Watts, Michael (2000)" The Great Tablecloth: Bread and Butter Politics, and the Political Economy of Food and Poverty" in Gordon Clark, Maryann Feldman and Meric Gertler Oxford Handbook of Economic Geography, Oxford University Press

Zachariah and Irudayarrajan (2014) Kerala's Gulf Connection; Economic and Social Impact of Migration, Orient Longmans

Table 1. Growth Rates of NSDP for the Four Southern States

\begin{tabular}{|c|c|c|c|c|c|c|c|c|c|c|c|c|}
\hline & \multicolumn{6}{|c|}{$\begin{array}{l}\text { Net State Domestic Product } \\
\text { (1999 prices, Rs. Million) }\end{array}$} & \multicolumn{5}{|c|}{$\begin{array}{l}\text { Net State Domestic Product Growth Rate } \\
\text { (percent) }\end{array}$} & \multirow[b]{3}{*}{$\begin{array}{c}2008-09-2011 \\
12\end{array}$} \\
\hline & \multirow[t]{2}{*}{$1960-61$} & \multirow[t]{2}{*}{$1970-71$} & \multirow[t]{2}{*}{ 1980-81 } & \multirow[t]{2}{*}{$1990-91$} & \multirow[t]{2}{*}{$2000-01$} & \multirow[t]{2}{*}{ 2007-08 } & $\begin{array}{l}1960-61 \\
\text { to }\end{array}$ & $\begin{array}{l}1970- \\
71 \text { to }\end{array}$ & $\begin{array}{l}1980- \\
81 \text { to }\end{array}$ & $\begin{array}{l}1990- \\
91 \text { to }\end{array}$ & $\begin{array}{l}1999- \\
2000 \text { to }\end{array}$ & \\
\hline & & & & & & & $1969-70$ & $\begin{array}{c}1979 . \\
80\end{array}$ & $\begin{array}{c}1989- \\
90\end{array}$ & $\begin{array}{l}1998- \\
1999\end{array}$ & 2007-08 & \\
\hline \multicolumn{13}{|l|}{$\begin{array}{l}\text { Southern } \\
\text { States }\end{array}$} \\
\hline \multirow{5}{*}{$\begin{array}{l}\text { Andhra } \\
\text { Pradesh } \\
\text { Karnataka } \\
\text { Kerala } \\
\text { Tamil Nadu } \\
\text { Average } \\
\end{array}$} & 198,714 & 264,990 & 366,245 & 679,094 & $1,260,347$ & 2,149,249 & 2.12 & 3.33 & 6.81 & 6.22 & 8.01 & \multirow{5}{*}{$\begin{array}{l}7.41 \\
6.90 \\
7.86 \\
8.86 \\
7.75\end{array}$} \\
\hline & 116,984 & 176,890 & 251,457 & 410,087 & 911,359 & $1,513,514$ & 4.32 & 4.14 & 5.57 & 8.95 & 6.75 & \\
\hline & 102,081 & 150,807 & 205,974 & 283,542 & 630,518 & $1,110,594$ & 3.72 & 2.18 & 2.87 & 8.57 & 7.73 & \\
\hline & 200,285 & 256,624 & 344,269 & 592,513 & $1,263,493$ & $1,940,987$ & 2.20 & 3.63 & 5.42 & 7.74 & 6.35 & \\
\hline & 154,516 & 212,328 & 291,986 & 491,309 & $1,016,429$ & $1,678,586$ & 3.09 & 3.32 & 5.17 & 7.87 & 7.21 & \\
\hline All India & $3,298,250$ & $4,741,310$ & $6,419,210$ & $10,835,720$ & $18,643,010$ & $31,297,170$ & 3.61 & 2.71 & 5.41 & 5.64 & 7.28 & \\
\hline
\end{tabular}

Figure 1: HDI and its dimensions: Indian states

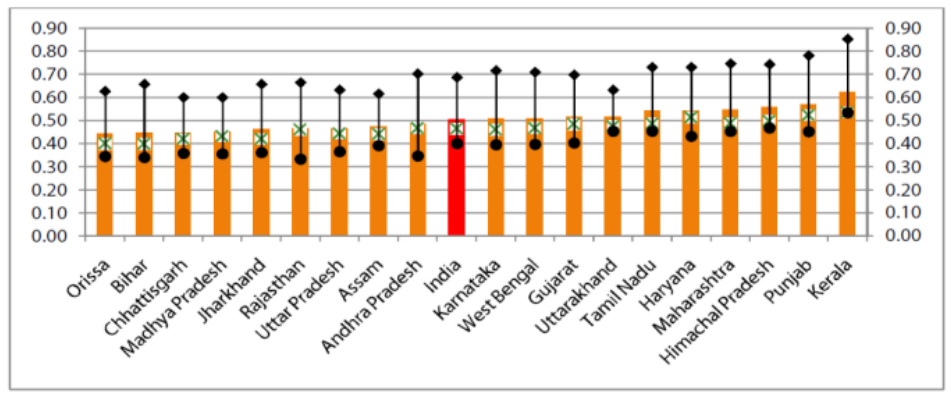

Notes: Vertical bars (orange color for states and red for India) indicate the HDl; dark black circles (inside the bars) indicate the education dimension index; cross within white squares, the income dimension index; and dark black diamonds (outside the bars), the health dimension index; and the states are arranged in ascending order of their HDIs. 
Table 2. Poverty Levels

\begin{tabular}{|c|c|c|c|c|c|c|c|c|}
\hline & \multicolumn{3}{|c|}{$\begin{array}{l}\text { Planning Commission } \\
\text { Population below poverty line } \\
2004-2005\end{array}$} & \multicolumn{3}{|c|}{$\begin{array}{l}\text { Tendulkar Committee } \\
\text { Poverty Headcount Ratio } \\
2004-2005\end{array}$} & \multicolumn{2}{|c|}{$\begin{array}{l}\text { Multidimensional Poverty } \\
\text { Index }\end{array}$} \\
\hline & $\begin{array}{c}\text { Rural } \\
\text { (percent) }\end{array}$ & $\begin{array}{c}\text { Urban } \\
\text { (percent) }\end{array}$ & $\begin{array}{l}\text { Combined } \\
\text { (percent) }\end{array}$ & $\begin{array}{c}\text { Rural } \\
\text { (percent) }\end{array}$ & $\begin{array}{c}\text { Urban } \\
\text { (percent) }\end{array}$ & $\begin{array}{c}\text { Total } \\
\text { (percent) }\end{array}$ & MPI & $\begin{array}{l}\text { Proportion of } \\
\text { Poor (percent) }\end{array}$ \\
\hline High Performers & & & & & & & & \\
\hline $\begin{array}{l}\text { Gujarat } \\
\text { Haryana }\end{array}$ & $\begin{array}{l}19.1 \\
13.6\end{array}$ & $\begin{array}{l}13.0 \\
15.1\end{array}$ & $\begin{array}{l}16.8 \\
14.0\end{array}$ & $\begin{array}{l}39.1 \\
24.8\end{array}$ & $\begin{array}{l}20.1 \\
22.4\end{array}$ & $\begin{array}{l}31.8 \\
24.1\end{array}$ & $\begin{array}{l}0.205 \\
0.199\end{array}$ & $\begin{array}{l}41.5 \\
41.6\end{array}$ \\
\hline Punjab & 9.1 & 7.1 & 8.4 & 22.1 & 18.7 & 20.9 & 0.193 & 40.1 \\
\hline Maharashtra & 29.6 & 32.2 & 30.7 & 47.9 & 25.6 & 38.1 & 0.120 & 26.2 \\
\hline West Bengal & 28.6 & 14.8 & 24.7 & 38.2 & 24.4 & 34.3 & 0.317 & 58.3 \\
\hline Southern States & & & & & & & & \\
\hline Andhra Pradesh & 11.2 & 28.0 & 15.8 & 32.3 & 23.4 & 29.9 & 0.211 & 44.7 \\
\hline Karnataka & 20.8 & 32.6 & 25.0 & 37.5 & 25.9 & 33.4 & 0.223 & 46.1 \\
\hline Kerala & 13.2 & 20.2 & 15.0 & 20.2 & 18.4 & 19.7 & 0.065 & 15.9 \\
\hline Tamil Nadu & 22.8 & 22.2 & 22.5 & 37.5 & 19.7 & 28.9 & 0.141 & 32.4 \\
\hline Laggards & & & & & & & & \\
\hline Bihar & 42.1 & 34.6 & 41.4 & 55.7 & 43.7 & 54.4 & 0.499 & 81.4 \\
\hline Madhya Pradesh & 10.7 & 42.1 & 38.3 & 53.6 & 35.1 & 48.6 & 0.389 & 69.5 \\
\hline Orissa & 46.8 & 44.3 & 46.4 & 60.8 & 37.6 & 57.2 & 0.345 & 64.0 \\
\hline Rajasthan & 18.7 & 32.9 & 22.1 & 35.8 & 29.7 & 34.4 & 0.351 & 64.2 \\
\hline Uttar Pradesh & 33.4 & 30.6 & 32.8 & 42.7 & 34.1 & 40.9 & 0.386 & 69.9 \\
\hline All India & 28.3 & 25.7 & 27.5 & 41.8 & 25.7 & 37.2 & 0.296 & $\mathbf{5 5 . 4}$ \\
\hline
\end{tabular}

Table3. Sectoral Growth Rates

\begin{tabular}{|c|c|c|c|c|c|c|c|c|c|c|c|c|c|c|c|}
\hline & \multicolumn{5}{|c|}{ Agrkattaral Secteor } & \multicolumn{5}{|c|}{ Moineflacturing Secter } & \multicolumn{5}{|c|}{ Sermice Sector } \\
\hline & \multicolumn{2}{|c|}{$\begin{array}{l}\text { share in stote } \\
\text { income (0.9) }\end{array}$} & \multicolumn{3}{|c|}{$\begin{array}{l}\text { inceme Growth rote } \\
\text { Cag }\end{array}$} & \multicolumn{2}{|c|}{$\begin{array}{l}\text { share in strote } \\
\text { income (X) }\end{array}$} & \multicolumn{3}{|c|}{$\begin{array}{c}\text { income Growet rote } \\
\text { avg }\end{array}$} & \multicolumn{2}{|c|}{$\begin{array}{l}\text { Share in stroce } \\
\text { income (Dy) }\end{array}$} & \multicolumn{3}{|c|}{$\begin{array}{l}\text { Ancome Growth rote } \\
\text { (0.9) }\end{array}$} \\
\hline & $\begin{array}{l}60-61 \\
60 \\
62-x 0\end{array}$ & $\begin{array}{c}00-01 \\
\text { to } \\
07-0,\end{array}$ & $\begin{array}{c}60-61 \\
60 \\
69-70\end{array}$ & $\begin{array}{l}9091 \\
\text { to } \\
9599\end{array}$ & $\begin{array}{c}9900 \\
\text { to } \\
\text { or.as }\end{array}$ & $\begin{array}{c}60-61 \\
10 \\
69-70\end{array}$ & $\begin{array}{c}00-01 \\
\text { to } \\
07-68\end{array}$ & $\begin{array}{c}60-61 \\
10 \\
69-70\end{array}$ & $\begin{array}{l}90-91 \\
\text { to } \\
50-90\end{array}$ & $\begin{array}{c}9200 \\
\text { to } \\
0808\end{array}$ & $\begin{array}{c}60.61 \\
60 \\
69-10\end{array}$ & $\begin{array}{l}00-01 \\
\text { to } \\
0808\end{array}$ & $\begin{array}{c}60-61 \\
t 0 \\
69-70\end{array}$ & $\begin{array}{l}9091 \\
\text { to } \\
95-99\end{array}$ & $\begin{array}{c}59-00 \\
\text { to } \\
07-08\end{array}$ \\
\hline Mech Pertormens & & & & & & & & & & & & & & & \\
\hline Gejarat & 52 & 28 & 3.62 & 9.72 & 2.200 & 27 & 25 & 3.24 & 2.2 .89 & 9.53 & 30 & 46 & 3.64 & 20.87 & 8.66 \\
\hline Maryano & 63 & 25 & 6.96 & 2.34 & 3.23 & 22 & 27 & 6.27 & 6.27 & 8.23 & 29 & 47 & 3.72 & 7.70 & 22.52 \\
\hline Aunjab & 37 & 25 & 0.67 & 4.58 & 4.87 & 27 & 27 & 5.50 & 7.03 & 5.26 & 34 & $\omega$ & 4.91 & 9.34 & 7.94 \\
\hline Maharashera & 52 & 36 & 4.06 & 2.62 & 2.26 & $\boldsymbol{\gamma}$ & 23 & 7.40 & 5.94 & 4.87 & 35 & 42 & 3.04 & S. 8.8 & 5.46 \\
\hline West Bencal & 42 & 24 & 2.75 & 6.67 & 2.27 & 17 & 9 & 2.62 & 8.25 & 5.28 & 23 & ss & 4.03 & 9.72 & 7.37 \\
\hline Averace & 49 & 23 & 3.15 & 4.98 & 4.85 & 24 & 16 & 5.01 & 7.86 & 6.63 & 28 & so & 3.87 & 8.70 & 8.39 \\
\hline $\begin{array}{l}\text { Souchern States } \\
\text { Andhra Pradesh }\end{array}$ & 59 & 25 & 105 & 4.21 & 636 & 7 & 10 & 609 & 694 & 5.66 & 28 & 52 & 3.07 & 7.35 & 8.48 \\
\hline Karnataka & 48 & 20 & 4.21 & 6.68 & ast & 12 & 14 & 6.85 & 22.27 & 1041 & 24 & 53 & 4.24 & 983 & 8.78 \\
\hline Kerala & 53 & 24 & 2.39 & 276 & 2.65 & 212 & 8 & 5.98 & 4.69 & 4.53 & 26 & 59 & 4.99 & 24.02 & 7.85 \\
\hline Tamal Nade & 28 & 23 & -0.73 & 7.60 & 206 & 27 & 27 & 5.77 & 6.28 & 6.30 & 48 & 59 & 3.68 & 2.20 & 7.70 \\
\hline Averace & 47 & 28 & 2.72 & 5.31 & 2. 88 & 12 & 12 & 6.18 & 7.49 & 6.72 & 31 & 56 & 4.00 & 10.08 & 8.20 \\
\hline \multicolumn{16}{|l|}{ Laceards } \\
\hline Eahar & 69 & 21 & 098 & 0.46 & 3.85 & 6 & 14 & 8.18 & 4.68 & 12.78 & 20 & 47 & 2.24 & 7.75 & 8.15 \\
\hline Machya Pradesh & 53 & 22 & 2.55 & 3.82 & 5.78 & 7 & 12 & 8.01 & 10.83 & 10.03 & 21 & 47 & 294 & 9.89 & 5.82 \\
\hline Oriss: & 9 & 24 & 5.88 & 6.08 & 3.95 & 2 & 9 & 8.09 & 5.08 & 12.75 & 16 & so & 3.44 & 6.66 & 8.10 \\
\hline Rajasthan & 58 & 29 & 2.91 & 4.07 & 9.54 & 10 & 9 & 2.79 & 2.27 & 4.02 & 28 & 44 & 3.90 & 20.74 & 6.09 \\
\hline Uttar Pradesh & 53 & 30 & 2.79 & 2.24 & 2.92 & 8 & 10 & 5.78 & 2.81 & 5.49 & 29 & 46 & 2.73 & 5.57 & 6.15 \\
\hline Averace & 49 & 25 & 2.82 & 3.34 & 5.02 & 7 & 22 & 6.37 & 6.93 & 2.82 & 23 & 47 & 2.85 & 2.12 & 6.86 \\
\hline Averace of 14 states & 48 & 23 & 2.62 & 4.49 & 4.34 & 10 & 23 & 5.83 & 7.42 & 7.46 & 27 & so & 3.5 .4 & 3.89 & 7.79 \\
\hline All lindio & 40 & 19 & 1.99 & 3.28 & 2.95 & 12 & 15 & 5.62 & 6.03 & 7.68 & 39 & 60 & 4.98 & 6.95 & 9.01 \\
\hline
\end{tabular}


Table 4. Gini Coefficient of Distribution of Consumption: 1973-74 to 2009-10

\begin{tabular}{|l|c|c|c|c|c|c|c|c|c|c|c|c|c|c|}
\hline & $1973--$ & 74 & $1977--$ & 78 & $1983--$ & 84 & $1993--$ & 94 & $1999--$ & 2000 & $2004--$ & 05 & $2009--$ & 10 \\
\hline & $\mathrm{R}$ & $\mathrm{U}$ & $\mathrm{R}$ & $\mathrm{U}$ & $\mathrm{R}$ & $\mathrm{U}$ & $\mathrm{R}$ & $\mathrm{U}$ & $\mathrm{R}$ & $\mathrm{U}$ & $\mathrm{R}$ & $\mathrm{U}$ & $\mathrm{R}$ & $\mathrm{U}$ \\
\hline AP & 0.288 & 0.288 & 0.298 & 0.319 & 0.292 & 0.306 & 0.285 & 0.320 & 0.235 & 0.313 & 0.289 & 0.370 & 0.278 & 0.382 \\
\hline KAR & 0.277 & 0.291 & 0.321 & 0.342 & 0.299 & .0 .330 & 0.266 & 0.315 & 0.241 & 0.323 & 0.263 & 0.364 & 0.235 & 0.334 \\
\hline KER & 0.314 & 0.370 & 0.353 & 0.356 & 0.330 & 0.371 & 0.288 & 0.338 & 0.270 & 0.321 & 0.341 & 0.400 & 0.417 & 0.498 \\
\hline TN & 0.269 & 0.305 & 0.319 & 0.333 & 0324 & 0.347 & 0.307 & 0.344 & 0.279 & 0.381 & 0.316 & 0.356 & 0.264 & 0.332 \\
\hline
\end{tabular}

Source: Planning Commission.

Table 5. Kerala fiscal Deficits; The Domar Gap (Percentages)

\section{Kerela - Domar Gap (Percentages)}

\begin{tabular}{|l|l|l|l|l|l|l|l|l|l|}
\hline & $\begin{array}{l}2007- \\
2008\end{array}$ & $\begin{array}{l}2008- \\
2009\end{array}$ & $\begin{array}{l}2009- \\
2010\end{array}$ & $\begin{array}{l}2010- \\
2011\end{array}$ & $\begin{array}{l}2011- \\
2012\end{array}$ & $\begin{array}{l}2012- \\
2013\end{array}$ & $\begin{array}{l}2013- \\
2014\end{array}$ & $\begin{array}{l}2014- \\
2015\end{array}$ & $\begin{array}{l}2015- \\
2016\end{array}$ \\
\hline Rd/gsdp & 2.28 & 1.35 & 2.18 & 1.36 & 2.61 & 2.68 & 1.54 & 1.53 & 1.42 \\
\hline Fd/gsdp & 3.68 & 3.16 & 3.42 & 2.87 & 4.16 & 4.29 & 3.26 & 3.10 & 3.05 \\
\hline Debt/gsdp & 33.44 & 31.47 & 30.81 & 29.20 & 29.04 & 29.64 & 28.93 & 28.29 & 27.71 \\
\hline Growrth rate & & 21.30 & 14.57 & 15.96 & 14.26 & 13.46 & 15.35 & 15.41 & 14.50 \\
\hline Interest rate & & 7.85 & 7.89 & 7.60 & 7.49 & 7.47 & 7.42 & 7.74 & 7.47 \\
\hline Domar gap & & 13.45 & 6.69 & 8.36 & 6.77 & 5.99 & 7.93 & 7.68 & 7.03 \\
\hline
\end{tabular}

Source: Ministry of Finance, Kerala 